\title{
Study Of Behaviour Of Indian Mongoose Herpestis Javanicus
}

\author{
Dr Rashmi Sharma \\ SPC GCA, Ajmer, Rajasthan, India
}

\begin{abstract}
Mongoose is small feliform carnivores that are native to southern Eurasia and Africa. The genus Suricata Suricata suricata commonly called meercat is found in South Africa. Herpestidae is placed within the suborder Feliformia, together with the cat, hyena, and civet families. Mongoose live in South Asia, Africa, Fiji, Puerto Rico, Caribbean and Hawaiian islands where they are an introduced sp. Mongooses have receptors for acetylcholine, like the receptors in snakes so it is impossible for snake neurotoxin venom to attach to them. Pigs, Honey badgers, Hedgehogs and mongooses all have modifications to the receptor pocket that prevents the snake venum Alpha neurotoxin from binding. Behaviour of small asian mongoose is syudied in the present paper.
\end{abstract}

Keywords: Behaviour, Small Asian Mongoose.

Classification

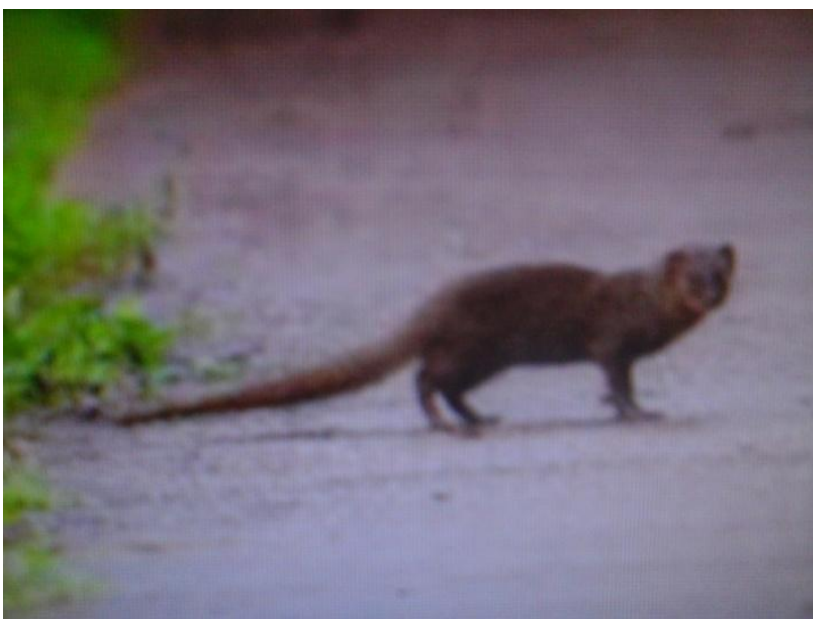

Indian mongoose Herpestes javanicus.

$\begin{array}{ll}\text { Kingdom } & \text { Animalia } \\ \text { Phylum } & \text { Chordata } \\ \text { Class } & \text { Mammalia } \\ \text { Order } & \text { Carnivora } \\ \text { Sub Order } & \text { Feliformia } \\ \text { Family } & \text { Herpestidae } \\ \text { Genus } & \text { Herpestes javanicus }\end{array}$

\section{Introduction}

Mongoose are terrestrial, Diurnal, viverrids, opportunistic feeders, feed on insects, crabs, earthworms, lizards, birds eggs, and carrion and rodents .M are weasel like animal 26' in length, long brownish body, short legs and a tail as long as the body. Small rounded ears, pointed nose, active during day. Mongoose are well known for their ability to fight and kill venomous snakes (cobras) due to their agility, coat and acetylcholine receptors that make them immune to snake venum.

They avoid cobra and have no particular affinity for consuming its meat. They have extreme difficulty in combating vipers and constricters. Cobras and other elapids lose fighting energy through their bluff. They can learn simple tricks. They can be semidomesticated and are kept as pets of control vermins imported into west indies to kill rats. They destroyed most ground based fauna. 


\section{Social Behavior}

Mongoose are highly social animals. Living in a group of 6-40 individuals known as packs or mobs. Groups are lead by dominant alfa male and dominant female who mate and reproduce. Mongoose live in cooperative society where each member of pack has a specific job and subsequent duties some are hunters some are baby sitters Those who live in group will take turn being sentinents. The sentinents stand on their Hind legs on higher ground looking all around them for danger If they spot a potential threat they will let out an alarm call so left of family members retreat to safety. The guard duty rotates every 45 min to 1 hour. Mongoose is small animal an excellent hunter with keen senses of smell sight and hearing and remarkable reflexes.

\section{Reproductive Behavior}

Mongoose have no set breeding season they can mate any time of the year as long as they are healthy and well nourished. They can breed from two to three times a year. The timing of the reproduction is set based on the length of the day. Those who are ready to mate will make giggling sound to alert members of opposite sex. Females show restlessness and increased marking. One oestrous female may shown interests by several males. The males exhibit screaming, barking and chasing among themselves. The female accepts the male that is most dominant in the group. Some species will also use scent marking around their territory to signal their readiness to reproduce. Ovulation in females is induced by copulation.

Male and female are both polygamous. Engage in sexual intercourse several times a day during oestrus. Birth takes place at night and after the sunset. Pregnancies occur most frequently prior to the summer the summer solstice north and south of the equater. The cycle of the male reproductive tract increases after winter solistice.(Gorman 1975). After mating the female carry their young for a number of weeks. The exact gestation period varies among species before giving birth to their litter in a den or burrow. At birth the back of the back of the young is covered with neutral grey hair and only a small amount of hair on the abdomen. It ways $21 \mathrm{~g}$ and vibrissae are prominent. They have well developed claws, closed ears, with mewling vocalizations. Eyelashes are also visible (Nellis \&Everhard 1983). Two weeks after birth their incisors Are in placeand canines have come out. By the 22nd week all permanent teeth are there.

Eye opening occurs 17-20 days after birth. By 4 month $2 / 3$ body mass is attained and

Spermatogenesis begins when body mass is $400 \mathrm{gm}$. Closure of skull suture indicates age. The average size of litter is $2-3$ young. Sexual maturity in female occurs in 10 months of age and males at 4 months. Snake charmers keep mongoose for mock fights with snakes. They hunt insects, mice, rats, lizards, snakes, King cobra they are immune to venom of scorpions and snakes. Although repeated sting or strike may siken and even kill them. Mongoose display simple tools crack open eggs, nuts, shelled creatures crabs, mollusks, by dropping or throwing them on rocks. Some raise up on their hind legs with item in their forepaws and drop it on a stone they look cute and cuddly fierce predators.

\section{Activity}

They move in a graceful way. Climb but not far above the ground. When They are in an open area they stay close to the ground in a slinking manner. They are not willing to enter water more than a few centimeter deep. They have a number of postures, sit in a vertical position on upper leg. When more height is needed they stand straight on hind feet support of muscular tail. Sleeping posture curling by curling tight circle with weight support by hind quarters and shoulders and snout pointing vertically.

\section{Communication}

Mark productively by wiping object with their anal pad. Marking as a displacement activity by the overpowered in agonistic encounters (Nellis 7 Everard 1983.) Variations in vocalizations weep, honk, squawk, ruck-a-ruck, spit, bark, chuck, scream and growl.(Mulligan 7 Nellis 1975).

\section{Juvenile Behavior}

At 4 weeks of age young make their 1st outings . and also follow mother on 1st hunting trip 96 weeks old. Young mongoose display strong following response (Nellis 7 Everard 1983).Extreme food envy from early age to adulthood. The animal fed to capacity will forcefully try to take food. The instinct is used by mother as a way of teaching young to feed. 


\section{Antipredator Behavior}

The animal is swift and aggressive and can dominate predator five times larger than it. During struggle it arch its back and tail along with piloerection.

\section{References}

[1]. Csurhes, Steve and Paul Fisher (2010). Indian mongoose Herpestes javanicus pest risk assessment. 5-6.

[2]. Ebisu, R.J. and G.C. Whittow. 1976. Temperature regulation in the small Indian mongoose (Herpestes auropunctatus 0. Comp. Biochem. Physiol., 54: 309-313.

[3]. Gorman, M.L. 1975. The diet of ferel Herpestes auropunctatus in the Fijan island. J. zool.London, 175: 273-278.

[4]. Hays, WST and Conant, 2007. Biology and impact of Pacific island invasive species, worldwide review of effect of small Indian mongoose, Herp[estes javanicus. Pacific Science, 61:3-16.

[5]. Mulligan, B.E., and D.W. Nellis. 1975. Vocal repertoire of the m H. auropunctatus. Behaviour, 55: $237-267$.

[6]. Nellis, D.W., and C.O.R. Everard, 1983. The biology of mongoose in the Caribbean. Stud. Fauna Curacao Caribbean island, 64: 1-162.

[7]. Nellis, D.w. and J.J. Mc Manus. 1974. Thermal tolerance of the mongoose, Herpestes auropunctatus J. Mamm., 55: 645646.

[8]. Wozencraft, W.C.(2005). Order Carnivora. In Wilson, D.E.; Reeder, D.M. Mammal species of the world: A Taxonomic and Geographic Reference(3rd ed.). Johns Hopkins University Press. Pp. 562-571. ISBN 978-0-8018-8221-0.0CLC 62265494.

[9]. Vaughan, Terry A.; James M. Ryan Nicholas J. Czaplewski (2010) Mammology . Jones \& Baartlet Learning, P300. ISBN 7637-6299-7.

[10]. Lydekker, R. 1984. A handbook to the carnivore. Part 1, Cats, civets, and mongooses London: Allen.

[11]. "Dictionary. Com; mongoose “. Retrieved 2008-08-22.

[12]. Merriam-Webster: mongoose. Retrieved 2006-04-12.

[13]. Macdonald. D., ed. (2009). The Encyclopedia of Mammals. Oxford: Oxford University Press. p. 660. ISBN 978-0-19956799-7.

[14]. Hedges, Stephen. " Science: Mongoose secret is to copy its prey " (http://www. Newscientist.com/article/mg 15320642.500-science-mongoose-secret-is-to-copy-its-prey.html);New Scientist; 11 january 1997. Retrieved 16 November 2007.

[15]. Drabeck, D.H. Dean, A.M.; Jansa, S.A. (JUNE 1 2015). Why the honey Badger don't care: Convergent evolution of venum targeted nicotinic acetylcholine receptors in mammals That survive venomous snake bites. Toxicon (Elsevier ) 99 : 68.doi:10. 1016/j.toxicon.2015.03.007.

[16]. “Animal Diversity Web: Herpestes ichneumon." Retrieved 2006-04-12.

[17]. "How the mongoose Defeats the snake." Retrieved 2010-10-25.

[18]. Mondadori, Arnoldo, ed.(1988). Great Book of the Animal Kingdom. New York; Arch Cape Press .p. 301.

[19]. Sherman, D.M. (2002) Tending animals in the global village. A Guide to international veterinary medicine. Philadelphia : Lippincott Williams \& Wilkins. P.45. ISBN 0683180517.

[20]. Animals whose importation is banned under the Lacey Act. Retrieved 2006-04-12.Poushali Ganguly. Mongoose Facts. Buzzle.

[21]. Marshall, Tom. Mongoose teamwork hides darker side. Retrieved 24 Feb 2014.

[22]. Kuber Golden Temple. Kubergoldentemple.org.

[23]. Hazardous substances and new organisms act 2003- Schedule 2 Prohibited new organisms. New Zealand Government. Retrieved 26 january 2012.

[24]. Barycka, EWA (2005). Evolution and systematic of the feliform carnivore. Mammlian Biology 72 (5);257-282, doi; 10.1016/jmambio.2006.10.011

[25]. Veron, G.; Colyn, M.; Dunham, A.E.; Taylor, P.; Gaubert, P. (2004). Molecular systematic and origin of sociality in mongoose (Herpestidae, Carnivora). Molecular phylogenetics and evolution 30 (3): 582-598.

[26]. Patou, M. ; Mclenachan, P.A.;Morley, C.G.; Couloux, A.; Jennings, A.P.;Veron, G. (2009). Molecular phylogeny of the Herpestes (Mammalia, Carnivora0 with a special emphasis on the Asian Herpestes." Molecular Phylogenetics and Evolution 53 (1): 69-80. doi: 10. 1016/ jympev.2009.05.038. 